\author{
Локтіонова-Ойцюсь Олександра \\ Олександрівна, \\ аспірантка Київського університету \\ імені Бориса Грінченка \\ ORCID 0000-0002-0865-0150 \\ o.loktionova@kubg.edu.ua
}

\title{
УКРАЇНСЬКЕ МУЗИЧНЕ ТЕЛЕБАЧЕННЯ 1990-Х - 2000-Х РОКІВ ЯК СОЦІКУЛЬТУРНИЙ ТА МИСТЕЦЬКИЙ ФЕНОМЕН
}

\begin{abstract}
Мета роботи: дослідження процесу становлення музичного телебачення на теренах України в 1990-х 2000-х роках. Методологія дослідження полягає у застосуванні загальних принципів наукового пізнання, які відповідають сучасному культурологічному дискурсу, що зумовило використання структурнофункціонального, системно-аналітичного, описового та компаративного дослідницьких методів для аналізу складових досліджуваного феномена. Наукова новизна одержаних результатів полягає у виявленні та системному узагальненні форм музичних жанрів українського телебачення, які існували в період 3 1990-х по 2000-ні роки. Висновки. У статті доводиться, що дослідження українського музичного телебачення у ХХ столітті, є реально актуальним і вимагає подальшого цілісного соціологічного та культурологічного осмислення й аналізу. Надано класифікацію жанрів українського музичного телебачення минулого століття та висвітлено сутність понять інфотейнмент та інфомершіалс, а також визначено їх вплив на розвиток українського музичного телебачення в 1990-х - 2000-х роках.

Ключові слова: українське музичне телебачення, соціокультурний та мистецький феномен, жанри музичного телебачення, ХХ століття.
\end{abstract}

\section{Локтионова-Ойцюсь Александра Александровна, аспирантка Киевского университета имени Бориса Гринченко}

Украинское музыкальное телевидение 1990-х - 2000-х годов как социокультурный и художественный феномен

Цель работы: исследование процесса становления музыкального телевидения на территории Украины в 1990-х - 2000-х годах. Методология исследования заключается в применении общих принципов научного познания, которые соответствуют современному культурологическому дискурсу, что обусловило использование структурно-функционального, системно-аналитического, описательного и сравнительного исследовательских методов для анализа составляющих исследуемого феномена. Научная новизна исследования заключается в выявлении и системном обобщении форм музыкальных жанров украинского телевидения, которые существовали в период с 1990-х по 2000-е годы. Выводы. В статье доказывается, что исследование украинского музыкального телевидения в XX веке является реально актуальным и требует дальнейшего целостного социологического и культурологического осмысления и анализа. Предоставлена классификация жанров украинского музыкального телевидения прошлого века и освещены сущность понятий инфотейнмент и инфомершиалс, а также определено их влияние на развитие украинского музыкального телевидения в 1990-х и 2000-х годах.

Ключевые слова: украинское музыкальное телевидение, социокультурный и художественный феномен, жанры музыкального телевидения, XX век.

Loktionova-Oitsius Oleksandra, postgraduate of Kyiv University of Boris Grinchenko

Ukrainian music television of the 1990s - 2000s as a socio-cultural and artistic phenomenon

Purpose of the article: research into the process of formation of music television on the territory of Ukraine in the 1990s - 2000s. The methodology consists in the application of general principles of scientific knowledge, which correspond to the modern culturological discourse, which determined using of structural-functional, system-analytical, descriptive and comparative research methods for analyzing the components of the phenomenon under study. The scientific novelty of the research lies in the identification and system generalization of the forms of musical genres of Ukrainian television that existed from the 1990s to the 2000s. Conclusions. The article proves that the research of Ukrainian music television in the twentieth century is really relevant and requires further holistic sociological, cultural understanding and analysis. A classification of the genres of Ukrainian music television of the last century has been presented and the essence of the concepts of infotainment and infomercial has been highlighted as well as their influence on the development of Ukrainian music television in the 1990s and 2000s has been determined. XX century

Key words: Ukrainian music television, socio-cultural and artistic phenomenon, genres of music television,

(C) Локтіонова-Ойцюсь О. О., 2019 
Актуальність теми дослідження. Сучасне соціокультурне життя будь-якого українця включає як глобальні події, які відбуваються у ньому, так і технічний прогрес, який піддав еволюції музичне телебачення України у період з 1990-х по 2000-ні роки. У зв'язку з диференціацією FM-радіостанцій і посиленням інтерактивного характеру мас-медіа, індивідуалізацією наданої інформації слухачам, музичне телебачення в 90-х роках набуває величезної популярізації. Дослідження історичних подій, які відбувалися саме в той період, виявлення музичних жанрів українського телебачення XX століття допоможе сучасному науковцю віднайти найбільш популярні жанри та спрогнозувати їх подальший розвиток на телевізійній «ниві».

Аналіз досліджень i публікацій. Проблема музичного телебачення вивчалася та висвітлювалася у працях зарубіжних авторів: Н.Єфімової, Т.Куришевої, Г.Новікової, В.Падейського, О.Поберезнікової, А.Чернишова, О.Шерстобоєвої. Серед українських науковців: О.Невмержизька, А.Скорик, К.Кошак розглядали феномен музичного телебачення в аспекті телевізійної продукції, саме для дітей та молоді та як чинник їх морального виховання.

Мета дослідження - дослідити процес становлення музичного телебачення на теренах України в 1990-х - 2000-х роках та виявити існуючи на той час його жанри.

Виклад основного матеріалу. Виникнення музичного телебачення в 1990-х - 2000-х роках було пов'язано $з$ диференціацією FM-радіостанцій і посиленням інтерактивного характеру мас-медіа, індивідуалізацією наданої інформації. Перший музичний телеканал України OTV київської телекомпанії розпочав свою роботу 24 квітня 1998 року. Ефір телеканалу О-TV був побудований на базі серверного мовлення. Його становила популярна сучасна музика, інтерактивні розваги та послуги, новини українського та світового шоу-бізнесу, різні музичні програми. O-TV першим серед телеканалів СНД ввів у своєму ефірі інтерактивну систему замовлення кліпів за допомогою стаціонарного та мобільного телефону, який першим запропонував своїм телеглядачам цілодобовий SMS-чат в руховому рядку, тим самим збільшив інтерес аудиторії.

Згодом, у 2001 році розпочинають своє віщання два музичні телеканали M1 та Enter Music. Один із найпопулярніших музичних телеканалів M1, який позиціонує себе як Перший національний музичний канал та на сьогодні він $є$ лідером щодо кількості й різноманітності власних телепрограм. Enter Music переважно пропагував зарубіжну поп-музику. Він розпочав мовлення 1 червня 2001 року та припинив 14 квітня 2012 року. Ефір будувався за блочно-модульним принципом тобто, окремі регулярні програми заповнювали ефір із додавання інтерактивних послуг для глядачів. В музичному аспекті канал орієнтувався в-першу чергу на українських виконавців, у другу - на світових, та у третю - на виконавців з інших країн СНД.

90-ті роки - це був час змін форм правління, виробничих відносин, стилів та підходів до творчого розвитку музичних телепрограм України. У тележурналістишs з'являються нові поняття «бізнес», «проект», «зірка естради», «піар» (Public Relations -зв'язки з громадськістю), «менеджмент» (управління, моделювання), «продюсер» (довірена особа, що реалізує творчий проект), «кліп» (рекламний відеоролик артиста/гурту), «рейтинг» (порядковий показник, який відібражає затребуваність виконавця/колективу), «хіт-парад» або «чарт» (рейтинг популярності музичної продукції), «креативність» (здатність індивіда до креативного, нестандартного мислення), «імідж» (формований образ артиста гурту для емоційно-психологічного впливу на публіку), «рекордингова компанія» (виробництво та розповсюдження відео- та аудіо- продукції), «корпоратив» (влаштування колективного заходу, свята, вечірки), «харизма» близький слову «чарівність»- особистісні якості людину, здатної ефективно застосовувати їх для впливу на публіку) тощо, тобто, цілий перелік понять нових технологій музичного виробництва і функціонування популярної музики.

Комерційна модель музичного телебачення, яка почала своє існування на початку 90-х років, проголосила принцип: «Привертання уваги глядачів, а через нього - реклами за всяку ціну» $[1,4]$. Комерціалізація українського музичного телебачення сприяла тому, що інформація розважального характеру стала активно завойовувати місце в телеефірі. Це значно відбилося на контенті музичних телеканалів, а, отже, і на його жанрових складових.

В історії новітньої української естради найбільш плідним був період до 1998 р., коли розпочали свою роботу перші музичні телеканали M1 та O-TV. Вокальна естрада цієї доби, була яскравою, багатоманітною та різножанровою. Вона представлена творчістю таких майстрів естради як: В. Зінкевич, Н. Яремчук, М. Мозговий, С. Ротару, Н. Шестак, І. Попович, І. Бобул, Л. Сандулеса, О. Білозір, Т. Петриненко та ін., так і нових імен: І. Білик, В. Павлік, Самая-Т, І. Сказіна, М. Бурмака, Катя Chilly, Н. Могилевська, Руслана, В. Хурсенко, М. Одольська, К. Бужинська, О. Юнакова, Каріна Плай, Інеш, гурти «Табула Раса», «Брати Карамазови», «Плач Сремії», «Океан Ельзи», «Аква Віта», «Скрябін», «Грін Грей», «ВВ» та ін. 
У цей час почали з'являтися особи-управлінці (менеджери), які брали на себе функції «розкручування» артистів, назвавши себе модним словом «продюсер», та намагалися створити свій перший капітал для переходу в «шоу-бізнес». То були персони, які ініціювали початок музичного шоу-бізнесу на території колишніх радянських республік та розвивали комерційну сторону розважальної галузі (Б. Алібасов, А. Разін, Ю. Айзеншпіс, Й. Пригожин). Серед українських продюсерів 90-х відзначимо Ю. Нікітіна, В. Бебешка, В. Клімова, Ю.Рибчинського, С. Макієвського $[9,113-114]$.

Музичне телебачення в 1990-х роках стало частиною масової культури. Головними принципами відбору інформації для програм стали сенсаційність, яскравість і видовищність, драматизація подій. Інфотейнмент і інфомершіалс стали основними способами подачі інформації на музичному телебаченні. Дані явища значно позначилися на всіх жанрових формах музичного телебачення. Виходячи 3 цього, ми пропонуємо наступну класифікацію жанрів музичного телебачення, а також і їх характеристику.

Під час складання класифікаиії жанрів музичного телебачення ми спиралися на загальну класифікацію телевізійних жанрів, запропоновану В. Л. Цвік та Р. А. Борецьким в навчальних посібниках «Телевізійна журналістика» та «Інформаційні жанри телебачення»:

1. Інформаційні жанри;

2. Аналітичні жанри;

3. Жанрові форми інфотейнменту і інфомершіалс.

До інформаиійних жанрів музичного телебачення відносяться відеосюжет, виступ (монолог в кадрі), інтерв'ю, репортаж і прямі включення.

До аналітичних жанрів музичного телебачення відносяться коментар, огляд, бесіда і дискусія.

Розглянемо більш детальніше жанрові форми інфотейнмена і інфомершіалс. У зв'язку з цим особливий інтерес представляють такі явища, як інфотейнмент (infotainment) i інфомершіалс (infomercials). Термін «інфотейнмент» $\epsilon$ абревіатурним об'єднанням двох англійських слів: інформація (information) і розвага (entertainment). Інфотейнмент - це інформаційно-розважальні передачі, в яких телеглядачам пропонуються сюжети, інформаційна цінність яких мінімальна. Дуже часто для подібних передач використовувалася так звана «новина», яка $\epsilon$ тільки приводом для головної мети телепрограми - створення розважального сюжету.

Термін «інфомершіалс» також $є$ абревіатурним об'єднанням двох англійських слів: інформація (information) і рекламні оголошення (commercials). У випадку з інфомершіалс під виглядом інформації, події, історії телеглядачеві подається реклама. В цілому, інфотейнмент і інфомершіалс можна віднести до методів подачі інформації, для яких характерні розважальність $\mathrm{i}$ комерційна спрямованість. Інфотейнмент $\mathrm{i}$ інфомершіалс виникли на хвилі все більшою комерціалізації ЗМІ та диктату рейтингу.

Специфічним жанром музичного телебачення $є$ відеокліп. Відеокліп - це короткий телевізійний сегмент, як правило, знятий на кіноплівку, але призначений для показу по телевізору і в мережах Інтернет.

До жанрових форм інфотейнмену $і$ інфомершіалсу можна віднести пісенний відеокліп, відеосюжет, телешоу, відеофільм. Жанрові форми музичного телебачення за великим рахунком - це різні варіанти трансляцій виконання музичного твору, а також фільми музичної тематики $[1,5]$.

Саме в них, відокремлення складових засноване на домінуванні (або рівноправності) внутрішньо кадрової музичної складової над журналістською або екранною. Фонове сприйняття музичних телепрограм обумовлене самостійністю малих форм, таких як відеокліп, виступи, а також частою відсутністю сюжетних ліній між ними і повторюваністю в ефірі. Музична складова сучасних телеканалів припускає відсутність негативного чинника і спонукає до яких-небудь творчих дій учасників цього проекту.

Кінець 1970-х рр. та початок 1980-х рр. ознаменувався «відеобумом» у США: багато артистів випустили проморолики до релізу синглів [2]. За даними журналу «Billboard», у 1978 р. американські телепродюсери Д. Кроу і Ч. Хендерсон в денному ефірі телеканалу USA Networks запустили програму «Video Concert Hall», яка включала виключно відеокліпи. Фактично саме Кроу i Хендерсону «Billboard» привласнили винахід формату музичного телебачення у США. Проте, вперше, трансляцію відеокліпів почало кабельне телебачення Манхеттена в 1975 р., випустивши в ефір програму «Nightclubbing».

Відеокліп мав схожі риси з рекламним роликом та був спрямований на підвищення продажів. Але, незважаючи на це, відеокліп та рекламний ролік мають різну «генетику». Рекламні ролики 
спочатку знімалися за законами «великого кінематографу» та їх транслювали перед початком кіносеансів. Музичний ж відеокліп мав суто телевізійну природу, хоча і тут відчувався вплив кінематографа: асоціативність і образність відеорядів.

Серед образотворчих рішень в кліпі можна було відзначити наступні прийоми: прагнення до перфоменсу (у відеокліпі майже завжди присутні великі плани виконавця), наявність елементів хепенінга, використання поп-арту, що позначає культурне і часовий простір і ленд-арту, внутрішні мотиви і настрої тощо.

«Як явище культури, кліп тісно пов'язаний з молодіжною субкультурою, їі вітальними естетичними установками та музичними смаками» [3]. Досить часто в науково-популярній літературі можна зустріти термін «кліпова свідомість» [4] як продукт музичного телебачення і масової музичної культури. Вперше даний термін виник в 1990-х р. мав і негативний відтінок, пов'язаний $з$ тим, що кліпи формують звичку до поверхневого сприйняття дійсності у молоді [5].

Телешоу є однією з найпоширеніших жанровових форм музичного телебачення України. Це пояснюється специфікою музичного телебачення, тяжінням багатьох музичних телепрограм до «звуковидовищ». Само по собі, шоу $є$ заходом розважального характеру. Як правило, шоу проводиться перед публікою. До музичних телешоу можна віднести концерти, конкурси, ігри, реаліті-шоу, телемюзикли і ток-шоу $[6,57]$.

Концерт займає центральне місце серед музичних жанрів. Сучасні концерти реалізуються як естрадні шоу з посиленою роллю ефектного видовища і цілісною драматургією зі специфічною формою, яка «вибудувана в часі». Даний жанр припускає наявність знімального майданчика або іншого умовного простору, що виконує функцію сцени. Обов'язкова і наявність аудиторії. Важливою відмінністю концерту від трансляції $є$ реакція глядачів, яка $\epsilon$ елементом програми, який в деяких випадках може штучно стимулюватися.

Конкурс ззовні будується як концерт. Відмінністю $є$ те, що «глядачі в залі або біля екрану телевізора часто виконують функції «оціновувачів» дії, тобто виступають у ролі «глядацького журі» $[7,121]$. У даній моделі, телекомунікатор виступає в ролі організатора видовища, тому ми можемо віднести жанр телеконкурс до формату телешоу.

Важливою частиною розважального телебачення, в тому числі i музичного, є гра. Ïї відмінність від конкурсу в тому, що тут ведучий ставить глядачеві питання і отримує від нього пряму відповідь (вірну або ні). Як правило, в таких програмах розігрується будь-який цінний приз.

Музичні телефільми - екранізації мюзиклів - досить специфічна і рідкісна форма на телебаченні, яка була розповсюджена у 1990-х - 2000-х рр., оскільки це одна 3 найбільш трудомістких і високобюджетних форм на телевиробництві.

I у минулому столітті і на сьогоднішній день дуже популярною формою на музичному телебаченні є мюзикл (аба музична комедія) - музично-сценічний твір, в якому переплітаються діалоги, пісні, музика, танці, при цьому сюжет, як правило, нехитрий. Для мюзиклу характерні: видовищність, різноманітність тем для постановки, необмеженість у виборі засобів вираження для акторів. Мюзикли представляють собою цілу комерційну індустрію, поставлену на «потік» (Бродвей, Голлівуд, Вест-Енд). Кіномюзиклами мають одні з найбільших касових зборів у світовому прокаті. Жанр серіального телемюзиклу є одним з найперспективніших.

Жанр ток-шоу поєднує в собі сутнісні ознаки інтерв'ю, дискусії та ігри, але концентруються навколо особистості ведучого. Ведучий ток-шоу повинен володіти такими особистісними якостями, як розум, винахідливість, чарівність, гумор, уміння зацікавлено слухати, пластично рухатися. Істотні, також, і зовнішні обставини: певне місце і строго дотримувана циклічність випусків програми, розрахована на збудження у свідомості масового глядача стану «нетерплячого очікування наступної зустрічі».

Наприкінці XX століття у телеглядачів з'явилася можливість дивитися кліпи, ток-шоу, мюзикли, як на музичних каналах, так і в Інтернет мережі. Нажаль, прагнення забезпечити високий рейтинг комерційного мовлення змушувало телекомпанії відмовлятися від якісних, але низькорейтингових передач на користь програм, які збирають біля телеекранів масову аудиторію розрахованих на глядача 3 невибагливим смаками. Все це негативно впливало на формування моральних та духовних цінностей у телеглядачів, але в той же час було чинником для активного синтезу існуючих на той час жанрів та утворення нових форм на телебаченні України у XXI столітті.

Наукова новизна дослідження полягає у тому, що виявлено та узагальнено форми музичних жанрів українського телебачення, які існували в період з 1990-х по 2000-ні роки в Україні.

Висновки. Безумовно, окреслені питання потребують більш детального вивчення та аналізу, в межах же цієї роботи, підсумовуючи, зауважимо, що процес розвитку українського музичного 
телебачення у XX столітті відбувався активно, було окреслено класифікацію жанрів українського музичного телебачення минулого століття, в яку увійшли інформаційні жанри,

аналітичні жанри та форми інфотейнменту і інфомершіалс. В минулому столітті українське телебачення почало транслювати відеокліпи, рекламні ролики, телешоу та інші форми музичного телебачення, які i наш час $є$ актуальними та улюбленими для перегляду різними віковими категоріями глядачів.

\section{Jimepamypa}

1. Ефимова Н. Н. Художественно-эстетический анализ звукового эфирного пространства телерадиовещания : автореф. дис. ... д-ра искусствоведения : 17.00.03 / МИТРО. Москва, 2005. 280 с.

2. Курышева Т.А. Музыкальная журналистика и музыкальная критика : учебн. пособ. Москва : Владос-Пресс, 2007. 296 с.

3. Новикова А. А. Современные телевизионные зрелища: истоки, формы и методы воздействия : кн. Санкт-Петербург : Алетейя, 2008. 208 с.

4. Падейский В. В. Проектирование телепрограмм : учеб. пособ. Москва : ЮНИТИ-ДАНА, 2015. 239 с.

5. Поберезникова Е. В. Телевидение взаимодействия. Интерактивное поле общения : учеб. пособ. Москва : Аспект Пресс, 2004. 224 с.

6. Самая Т. В. Вокальне мистецтво естради як чинник культурного життя України другої половини XX - початку XXI століття : автореф. дис. канд. мистецтвознавства: 26.00.01 / НАКККІМ . Київ, 2018. 199 с.

7. Чернышов А. В. Структурирующие музыкальные тележанры. Вестник Томского государственного университета. Томск, 2012. 47-50 с.

8. Шерстобоева Е. А. Музыкальное телевидение: программные и структурно-функциональные особенности : автореферат дис. ... кандидата филологических наук : 10.01 .10 / Моск. гос. ун-т им. М.В. Ломоносова. Москва, 2009. 24 с.

\section{References}

1. Efymova, N. (2005). Artistic and aesthetic analysis of the broadcasting space of broadcasting. Moskva: MYTRO [in Russia].

2. Kurbsheva, T. (2007). Music journalism and music criticism. Moskva: Vlados-Press [in Russia]. [in Russia].

3. Novykova, A. (2008). Modern television shows: the origins, forms and methods of influence. SPb: Aletejja

4. Padejskyj, V. (1999). Designing TV programs. Moskva: JuNYTY-DANA [[in Russia].]. [in Russia].

5. Pobereznykova, E. (2004.). Television interaction. Interactive communication field. Moskva: Aspekt Press

6. Samaja, T. (2018). Vocal pop art as a factor in the cultural life of Ukraine in the second half of the XX beginning of the XXI century. Kyiv: NAKKKIM [in Ukrainian].

7. Chernushov, A. (2012). Structuring music carriages. Tomsjk: Visnyk Tomsjkogho nacionaljnogho universytetu. [in Russia].

8. Sherstobojeva, Je. (2009). Music TV: program and structural-functional features. Moskva: Mosk. nac. un-t im. M.V. Lomonosova [in Russia].

Стаття надійшла до редакиії 18.01.2019 p. 